\title{
Analisis Keterampilan Guru Dalam Komunikasi Dengan Peserta Didik Di SMA Negeri Tegaldlimo Banyuwangi
}

\author{
Muhamad Rosid \\ SMA Negeri Tegaldlimo Banyuwangi \\ Jalan Wijaya Kusuma No.1, Tegaldlimo, Banyuwangi \\ E-mail: Rosid994@gmail.com
}

\begin{abstract}
Abstrak
Tujuan dari penelitian ini adalah untuk menganalisis kompetensi guru dalam berkomunikasi dengan siswa yang memiliki kompetensi asopek pedagogis untuk guru di SMA Negeri Banyuwangi Tegaldlimo. Sampel penelitian ini adalah semua guru di SMA Negeri Banyuwangi Tegaldlimo, 48 guru yang terdiri dari 20 laki-laki dan 28 perempuan, 31 PNS dan 17 PNS. Penelitian ini adalah penelitian survei menggunakan kuesioner dan metode wawancara. Hasil penelitian ini menunjukkan bahwa, skor rata-rata keterampilan komunikasi untuk guru laki-laki adalah $69 \%$ dan untuk guru perempuan adalah $72,5 \%$, dan secara umum keterampilan guru dengan status PNS dalam berkomunikasi dengan siswa lebih baik daripada guru dengan non-PNS PNS. status. Kesimpulan: 1) Keterampilan guru dalam berkomunikasi dengan siswa di SMA Negeri Tegaldlimo pada umumnya berada dalam kisaran kriteria yang baik, 2) keterampilan guru PNS dalam berkomunikasi dengan siswa terbukti lebih baik daripada guru non-PNS, 3) Bimbingan guru diperlukan mengenai keterampilan komunikasi dengan siswa.
\end{abstract}

Kata Kunci: Keterampilan Guru, Komunikasi, Peserta Didik

Abstract

The purpose of this study is to analyze the teacher's competence in communication with students who are asopek of pedagogical competence for teachers in Banyuwangi Tegaldlimo State High School. The sample of this study was all teachers in Banyuwangi Tegaldlimo Public High School, 48 teachers consisting of 20 men and 28 women, 31 civil servants and 17 civil servants. This research is a survey research using questionnaire and interview method. The results of this study indicate that, the average score of communication skills for male teachers is $69 \%$ and for female teachers is $72.5 \%$, and in general the skills of teachers with civil servant status in communicating with students are better than those of teachers with non-status Civil servants. Conclusions: 1) Teachers 'skills in communicating with students in Tegaldlimo State High School are generally in a range of good criteria, 2) PNS Teachers' skills in communicating with students are proven to be better than those of Non-PNS Teachers, 3) Teacher guidance is needed about communication skills with students.

Keywords: Teachers' Skills, Communication, Guided Inquiry, Student

\section{Pendahuluan}

Pekerjaan Guru di abad 21 terasa semakin kompleks seiring dengan perkembangan teknologi dan ilmu pengerahuan secara global yang cepat dan tak terbatas oleh waktu dan ruang. Peran internet sangat penting membantu semua pekerjaan, khususnya teknologi komunikasi baik lokal maupun internasional. Kompetensi Guru profesional tidak lagi sekedar guru yang mampu mengajar dengan baik melainkan guru yang mampu menjadi pembelajar dan agen perubahan sekolah, dan juga mampu menjalin dan mengembangkan hubungan untuk peningkatan mutu pembelajaran di sekolahnya. Oleh karena itu, guru membutuhkan pengembangan profesional yang efektif khususnya kompetensi paedagogik.

Saputra (2013) merekomendasikan bahwa Guru diharapkan lebih peka untuk mengapresiasi keberhasilan siswa, memberi motivasi siswa, mampu menyampaikan materi pelajaran lebih komunikatif dan menarik [1]. Sementara hasil penelitian yang dilakukan Munandar dkk, (2013) melaporkan bahwa pada aspek mengembangkan kurikulum dan aspek memfasilitasi pengembangan potensi peserta didik, masih kurang optimal, hal ini dikarenakan oleh ketidaksiapan guru dalam mengelola pengembangan kurikulum KTSP ini sendiri dan masih menggunakan format pengembangan kurikulum yang berorientasikan pada kurikulum KBK [2]. Ningsih (2017) melaporkan bahwa kompetensi pedagogik guru dalam pengeloaan proses pembelajaran sudah baik, namun beberapa faktor yang menjadi hambatan guru dalam pengelolaan proses pembelajaran masih belum ada upaya nyata untuk mengatasinya [3].

Salah satu aspek kompetensi paedagogik yang harus dimiliki oleh Guru profesional adalah keterampilan berkomunikasi dengan peserta didik. Guru professional harus mampu berkomunikasi secara efektif, empatik dan santun dengan peserta didik dan bersikap antusias dan positif.

Menurut permendiknas No. 16 Tahun 2007, aspek keterampilan Guru dalam komunikasi dengan peserta didik yang di teliti meliputi keterampilan Guru dalam: 1) menggunakan pertanyaan untuk mengetahui pemahaman dan 
menjaga partisipasi peserta didik, termasuk memberikan pertanyaan terbuka yang menuntut peserta didik untuk menjawab dengan ide dan pengetahuan mereka, 2) memberikan perhatian dan mendengarkan semua pertanyaan dan tanggapan peserta didik, tanpamenginterupsi, kecuali jika diperlukan untuk membantu atau mengklarifikasi pertanyaan/tanggapan tersebut, 3) menanggapi pertanyaan peserta didik secara tepat, benar, dan mutakhir, sesuai tujuan pembelajaran dan isi kurikulum, tanpa mempermalukannya, 4) menyajikan kegiatan pembelajaran yang dapat menumbuhkan kerja sama yang baik antarpeserta didik, 5) mendengarkan dan memberikan perhatian terhadap semua jawaban peserta didik baik yang benar maupun yang dianggap salah untuk mengukur tingkat pemahaman peserta didik, 6) merespon pertanyaan peserta didik secara lengkap dan relevan untuk menghilangkan kebingungan pada peserta didik. Oleh karena itu penelitian ini bertujuan melakukan analisis keterampilan Guru dalam Komunikasi dengan peserta didik di SMA Negeri Tegaldlimo Banyuwangi.

\section{Metode Penelitian}

Jenis penelitian ini adalah penelitian Evaluasi dengan Sampel penelitian ini adalah seluruh Guru di SMA Negeri Tegaldlimo Banyuwangi, sejumlah 48 orang Guru yang terdiri dari 20 orang pria dan 28 orang wanita, yang sudah pegawai negeri (PNS) sebanyak 31 orang dan yang belum pegawai negeri (Non-PNS) sebanyak 17 orang.

Metode pengumpulan data dilakukan dengan cara kuesioner terhadap responden peserta didik yang pernah minimal satu tahun berada di kelas dimana guru mengajar. Responden untuk setiap guru sejumlah 50 peserta didik yang di tentukan secara random. Instrumen kuesioner mengacu pada 6 aspek keterampilan guru dalam komunikasi dengan peserta didik. Pengisian kuesioner oleh responden dilakukan secara langsung dan dikembalikan pada hari yang sama.

Data hasil kuesioner di kuantifikasikan dalam bentuk prosentase. Analisis keterampilan Guru dalam berkomunikasi dengan peserta didik dilakukan berdasarkan jenis kelamin dan berdasarkan status kepegawaian menggunakan analisis deskriptif dan analisis statistic t-Test dengan taraf signifikan 95\%. Sebagai dasar analisis deskriptif menggunakan kriteria seperti pada Tabel 1 berikut.

Tabel 1. Kriteria skor keterampilan guru dalam komunikasi

\begin{tabular}{|c|c|}
\hline Kriteria & Skor \\
\hline Sangat Baik & $76 \%-100 \%$ \\
\hline Baik & $51 \%-75 \%$ \\
\hline Kurang Baik & $26 \%-50 \%$ \\
\hline Tidak Baik & $0 \%-25 \%$ \\
\hline
\end{tabular}

\section{Hasil dan Pembahasan}

Data hasil penelitian yang diperoleh berdasarkan hasil kuesioner pada peserta didik berdasarkan jenis kelamin dan status kepegawaian Guru di SMA Negeri Tegaldlimo
Banyuwangi. Skor keterampilan Guru dalam berkomunikasi dengan siswa berdasarkan jenis kelamin (20 laki-laki, 28 perempuan) disajikan dalam Tabel 2 sebagai berikut.

Tabel 2. Keterampilan guru komunikasi berdasarkan jenis kelamin

\begin{tabular}{|l|c|c|}
\hline \multicolumn{2}{|c|}{ Aspek } & \multicolumn{2}{c|}{ Skor Guru } \\
\cline { 2 - 3 } & Laki & Perempuan \\
\hline Menggunakan pertanyaan & $73.00 \%$ & $70.00 \%$ \\
\hline $\begin{array}{l}\text { Perhatian dan mendengarkan semua } \\
\text { pertanyaan peserta didik }\end{array}$ & $66.00 \%$ & $74.00 \%$ \\
\hline $\begin{array}{l}\text { Menanggapi pertanyaan peserta } \\
\text { didik }\end{array}$ & $68.00 \%$ & $74.00 \%$ \\
\hline $\begin{array}{l}\text { Menyajikan pembelajaran } \\
\text { Mendengarkan dan perhatian } \\
\text { terhadap semua jawaban }\end{array}$ & $65.00 \%$ & $68.00 \%$ \\
\hline $\begin{array}{l}\text { Memberikan respon pertanyaan } \\
\text { peserta didik }\end{array}$ & $70.00 \%$ & $74.00 \%$ \\
\hline Rata-rata & $69.00 \%$ & $72,5 \%$ \\
\hline
\end{tabular}

Berdasarkan Tabel 2 hasil penelitian ini menunjukkan bahwa, rata-rata skor keterampilan Guru dalam 1) menggunakan pertanyaan untuk Guru laki-laki $73 \%$ dan untuk Guru perempuan 70\%, 2) memberikan perhatian dan mendengarkan semua pertanyaan dan tanggapan pesrrta didik untuk Guru laki-laki $66 \%$ dan untuk Guru perempuan $74 \%, 3)$ menanggapi pertanyaan untuk Guru laki-laki 68\% dan untuk Guru perempuan $74 \%$, 4) menyajikan pembelajaran untuk Guru laki-laki $72 \%$ dan untuk Guru perempuan $75 \%$, 5) mendengarkan dan memberi perhatian teehadap semua jawaban untuk Guru laki-laki $65 \%$ dan untuk Guru perempuan 68\%, 6) memberikan perhatian dalam merespon pertanyaan peserta didik untuk Guru lakilaki 70\% dan untuk Guru perempuan 74\%. Rata-rata skor keterampilan komunikasi untuk Guru laki-laki 69\% dan untuk Guru perempuan 72,5\%. Berdasarkan kriteria nketerampilan Guru dalam berkomunikasi dengan peserta didik menunjukkan rata-rata berada pada kriteria baik, berada pada rentangan skor $51 \%$ - 75\%. Selanjutnya data hasil penelitian disajikan dalam Gambar 1 sebagai berikut.

Gambar 1. Grafik keterampilan guru dalam berkomunikasi berdasarkan jenis kelamin

Hasil analisis t-Test menunjukkan bahwa keterampilan Guru dalam komunikasi dengan peserta didik pada aspek menggunakan pertanyaan antara Guru laki-laki dan Guru perempuan tidak berbeda secara nyata $(p>0,05)$. Keterampilan Gutru dalam memberikan perhatian dan mendengarkan semua pertanyaan dan tanggapan peserta didik Guru perempuan secara signifikan $(p<0,05)$ lebih baik di banding Guru laki-laki. keterampilan Guru dalam menanggapi pertanyaan Guru perempuan secara signifikan ( $p<0,05)$ lebih baik di banding Guru laki-laki. Sementara keterampilan Guru dalam menyajikan pembelajaran, keterampilan Guru dalam mendengarkan dan memberi perhatian terhadap semua jawaban, dan keterampilan Guru 
dalam memberikan perhatian dalam merespon pertanyaan antara Guru laki-laki dan Guru perempuan tidak berbeda secara signifikan $(\mathrm{p}>0,05)$.

Secara umum menunjukkan bahwa keterampilan guru dalam berkimunikasi dengan peserta didik tergolong kriteria baik, namun masih perlu dilakukan pembinaan kompetensi Guru, khususnya pada aspek keterampilan berkomunikasi dengan peserta didik. Analisis keterampilan Guru dalam berkomunikasi dengan peserta didik berdasarkan jenis kelamin tampak bahwa secara kodrat perempuan memiliki naluri keibuan, sehingga secara umum skor keterampilan berkomunikasi Guru perempuan lebih baik di banding Guru laki-laki. Tampak keterampilan Guru perempuan dalam berkomunikasi menonjol pada aspek perhatian dan mendengarkan semua pertanyaan peserta didik dan aspek keterampilan daaalam hal menanggapi pertanyaan peserta didik. Hal ini mengingat seacara alamiah seorang Ibu akan lebih mengutamakan perasaaan, sehingga akan lebih menjaga perasaan peserta didik.

Kondisi ini sesuai hasil penelitian Sumiarsi (2015) penelitian menunjukkan, bahwa masih dibutuhkan pembinaan Guru untuk mencapai kompetensi pedagogik sesuai Peraturan Menteri Pendidikan Nasional Nomor 16 Tahun 2007 [4]. Sementara hasil penelitian Suciani (2018) mebuktikan bahwa kompetensi pedagogik guru dalam aspek pemahaman terhadap peserta didik dan dalam/aspek pelaksanaan pembelajaran belum tergolong baik [5].

Selanjutnya skor keterampilan Guru berkomunikasi dengan siswa berdasarkan status kepegawaian Guru (31 Guru PNS, 17 Guru Non-PNS) disajikan dalam Tabel 3 sebagai berikut.

Tabel 3. keterampilan komunikasi guru berdasarkan status kepegawaian

\begin{tabular}{|l|c|c|}
\multirow{2}{*}{ Aspek } & \multicolumn{2}{|c|}{ Skor Guru } \\
\cline { 2 - 3 } & PNS & Non-PNS \\
\hline Menggunakan pertanyaan & $74.00 \%$ & $66.00 \%$ \\
\hline $\begin{array}{l}\text { Perhatian dan mendengarkan semua } \\
\text { pertanyaan peserta didik }\end{array}$ & $70.00 \%$ & $64.00 \%$ \\
\hline $\begin{array}{l}\text { Menanggapi pertanyaan peserta } \\
\text { didik }\end{array}$ & $72.00 \%$ & $62.00 \%$ \\
\hline $\begin{array}{l}\text { Menyajikan pembelajaran } \\
\begin{array}{l}\text { Mendengarkan dan perhatian } \\
\text { terhadap semua jawaban }\end{array}\end{array}$ & $70.00 \%$ & $68.00 \%$ \\
\hline $\begin{array}{l}\text { Memberikan respon pertanyaan } \\
\text { peserta didik }\end{array}$ & $72.00 \%$ & $70.00 \%$ \\
\hline Rata-rata & $72.00 \%$ & $66.00 \%$ \\
\hline
\end{tabular}

Berdasarkan Tabel.3 menunjukkan bahwa rata-rata skor keterampilan Guru dalam 1) menggunakan pertanyaan untuk Guru PNS 74\% dan untuk Guru Non-PNS 66\%, 2) memberikan perhatian dan mendengarkan semua pertanyaan dan tanggapan peserta didik untuk Guru PNS 70\% dan untuk Guru Non-PNS 64\%,3) menanggapi pertanyaan untuk Guru PNS 72\% dan untuk Guru Non-PNS 62\%, 4) menyajikan pembelajaran untuk Guru PNS 76\% dan untuk Guru Non-
PNS $66 \%$, 5) mendengarkan dan memberi perhatian teehadap semua jawaban untuk Guru PNS 70\% dan untuk Guru Non-PNS 68\%, 6) memberikan perhatian dalam merespon pertanyaan peserta didik untuk Guru PNS \% dan untuk Guru Non-PNS 70\%.

Rata-rata skor keterampilan komunikasi untuk Guru PNS $69 \%$ dan untuk Guru Non-PNS 72,5\%. Berdasarkan kriteria nketerampilan Guru dalam berkomunikasi dengan peserta didik menunjukkan rata-rata berada pada kriteria baik, berada pada renyangan skor $51 \%-75 \%$. Selanjutnya data hasil penelitian disajikan dalam Gambar 2 sebagai berikut.

Gambar 2. Grafik keterampilan guru dalam berkomunikasi berdasarkan ststus kepegawaian

Hasil analisis t-Test menunjukkan bahwa 4 aspek keterampilan Guru dalam komunikasi dengan peserta didik, antara lain aspek keterampilan menggunakan pertanyaan kepada peserta didik, keterampilan memberikan perhatian dan mendengarkan semua pertanyaan dan tanggapan peserta didik, keterampilan menanggapi pertanyaan peserta didik, dan keterampilan menyajikan pembelajaran pada Guru yang bersattus PNS secara signifikan $(\mathrm{p}<0,05)$ lebih baik dibanding Guru yang berstatus belum PNS. Sementara pada aspek keterampilan Guru dalam, keterampilan Guru dalam mendengarkan dan memberi perhatian terhadap semua jawaban, dan keterampilan Guru dalam memberikan perhatian dalam merespon pertanyaan antara Guru yang berstatus PNS dan Guru yang berstatus Non-PNS tidak berbeda secara signifikan $(\mathrm{p}>0,05)$.

Tampak secara umum keterampilan Guru dengan status PNS dalam berkomunikasi dengan peserta didik lebih baik dibandingkan dengan Guru cdengan status Non-PNS. Perbedaan menonjol terdapat pada keterampilan Guru PNS pada aspek: 1) menggunakan pertanyaan untuk mengetahui pemahaman dan menjaga partisipasi peserta didik, termasuk memberikan pertanyaan terbuka yang menuntut peserta didik untuk menjawab dengan ide dan pengetahuan mereka, 2) memberikan perhatian dan mendengarkan semua pertanyaan dan tanggapan peserta didik, tanpamenginterupsi, kecuali jika diperlukan untuk membantu atau mengklarifikasi pertanyaan/tanggapan tersebut, 3) menanggapi pertanyaan peserta didik secara tepat, benar, dan mutakhir, sesuai tujuan pembelajaran dan isi kurikulum, tanpa mempermalukannya, 4) menyajikan kegiatan pembelajaran yang dapat menumbuhkan kerja sama yang baik antarpeserta didik.

Sementara keterampilan berkomunikasi Guru NonPNS pada aspek 5) mendengarkan dan memberikan perhatian terhadap semua jawaban peserta didik baik yang benar maupun yang dianggap salah untuk mengukur tingkat pemahaman peserta didik, dan aspek 6) merespon pertanyaan peserta didik secara lengkap dan relevan untuk menghilangkan kebingungan pada peserta didik terbukti tidak berbeda secara signifikan dengan Guru dengan status PNS.

Hal ini mencerminkan bahwa Guru Non-PNS masih perlu bimbingan untuk melatih keterampilan berkomunikasi dengan peserta didik. Hal ini mengingat masa kerja guru Non-PNS rata-rata kurang dari 10 Tahun. Oleh karena itu 
keterampilan Guru dalam berkomunikasi saaangat penting karean berperan pada kualitas hasil pembelajaran.

Hasil penelitian Hidayat (2016), juga menunjukkan perbedaan pada kemampuan berkomunikasi guru secara verbal, non verbal, perbedaan kemampuan bergaul secara santun dan efektif dengan siswa-siswi di kelas, serta perbedaan kemampuan penguasaan teknologi komunikasi dalam proses belajar mengajar [6]. Selanjutnya, guru-guru di SMPN 1 Bukit mampu memadukan tiga kategori model komunikasi sekaligus (komunikasi satu arah, dua arah, dan transaksi), sedangkan pada SMPS Blang Panas, guru hanya mampu menerapkan model komunikasi satu arah saja.

Mengingat peran Guru sebagai fasilitator dalam proses pembelajaran, maka harus di sadari betapa pentingnya keterampilan Guru dalam komunikasi. Siahaan (2018), malaporkan bahwa keterampilan komunikasi guru menjadi syarat dalam memudahkan siswa dapat menerima dengan mudah bahan pembelajaran untuk mencapai perubahan kognitif, afektif dan psikomotorik [7]. Oleh karena itu, berdasarkan hasil penelitian ini, akan digunakan sebagai dasar untuk program pembinaan Guru menuju Guru professional.

\section{Kesimpulan dan Saran}

Berdasarkan hasil analisis data penelitian ini dapat di simpulkan bahwa keterampilan Guru dalam berkomunikasi dengan peserta didik di SMA Negeri Tegaldlimo secara umum berada pada rentangan kriteria baik. Keterampilan Guru PNS dalam berkomunikasi denga peserta didik terbukti lebih baik dibandingkan dengan keterampilan Guru NonPNS. Saran yang dapat diberikan setelah mengadakan penelitian ini adalah perlu dilakukan pembinaan Guru tentang keterampilan berkomunikasi dengan peserta didik.

\section{Ucapan Terima Kasih}

Saya ucapkan terima kasih kepada semua civitas SMA Negeri Tegaldlimo Banyuwangi atas kerja sama, bantuan, serta dukungan yang telah diberikan kepada saya.

\section{Daftar Pustaka}

[1] H. Saputra, 2013, "Studi tentang kemampuan berkomunikasi guru dalam meningkatkan motivasi belajar siswa pada kegiatan belajar mengajar di SDM 017 kota Samarinda," Journal Ilmu Komunikasi, Vol. 1, No. 1 : 290-300.

[2] A. Munandar, Sulistyarini, and A. Zakso, 2013, "Analisis kompetensi paedagogik guru dalam pembelajaran sosiologi di SMA negeri 1 Jawai," Jurnal Pendidikan dan Pembelajaran Khatulistiwa, Vol. 2, No. 9.

[3] D. H. Ningsih, 2017, "Analisis kompetensi paedagogik guru dalam pengelolaan proses pembelajaran di SD negeri 10 Mandonga," Wakapendik, Vol 2, No 7.

[4] N. Sumiarsi, 2015, "Analisis kompetensi paedagogik dan pengembangan pembelajaran guru SD negeri 041 Tarakan," Jurnal Kebijakan dan Pengembangan Pendidikan, Vol. 3, No.1.

[5] N. Suciana, "Analisis kompetensi paedagogik guru dalam pemahaman terhadap peserta didik di SD Negeri 009 Ganting kecamatan Salo," Jurnal Review Pendidikan dan Pengajaran, Vol.1 No.1, (2018).

6] W. Hidayat, 2016, "Komparasi model kompetensi komunikasi guru dalam proses belajar mengajar: studi kasus pada SMPN 1 Bukit dengan SMPS Blang Panas kecamatan Bukit kabupaten Bener Meriah provinsi Aceh” Jurnal Simbolika, Vol. 2, No. 1.

\section{(1) R}

